\title{
Cortical spreading depression and familial hemiplegic migraine 2015
}

\author{
Daniela Pietrobon \\ From Abstracts from the 1st Joint ANIRCEF-SISC Congress \\ Rome, Italy. 29-31 October 2015
}

The molecular and cellular mechanisms of the primary brain dysfunction leading to the onset of a migraine attack and to susceptibility to cortical spreading depression (CSD), the neurophysiological correlate of migraine aura and a likely trigger of the headache mechanisms, remain largely unknown and major open issues in the neurobiology of migraine. Our approach to these open questions is the study of the functional consequences of mutations causing familial hemiplegic migraine type 1 and type 2 (FHM1 and FHM2). FHM1 is caused by gain-of-function mutations in the neuronal CaV2.1 channel, a voltagegated calcium channel that plays a dominant role in controlling neurotransmitter release at brain excitatory and inhibitory synapses. FHM2 is caused by loss-of-function mutations in the glial alpha2 $\mathrm{Na} / \mathrm{K}$-ATPase, an isoform that is thought to have specific roles in $\mathrm{K}+$ and glutamate clearance by astrocytes and in astrocyte $\mathrm{Ca} 2+$ homeostasis. Knockin (KI) mouse models carrying FHM1 or FHM2 mutations show a lower threshold for CSD induction and a higher velocity of CSD propagation. We have investigated the cortical mechanisms underlying the facilitation of experimental CSD in FHM1 and FHM2 KI mice by studying synaptic transmission at cortical excitatory and inhibitory synapses and the rate of glutamate and $\mathrm{K}+$ clearance by cortical astrocytes in acute cortical slices. Our findings are consistent with the conclusion that increased activation of NMDA receptors due to enhanced cortical glutammatergic synaptic transmission in FHM1 and to reduced rate of glutamate clearance at cortical excitatory synapses in FHM2 contributes to the facilitation of CSD in FHM KI mice. The data from FHM mouse models support the view of migraine as a disorder of brain excitability characterized by dysregulation of the excitatory-inhibitory $E / I$ balance, and point to episodic disruption of the E/I balance and neuronal hyperactivity due to excessive

Correspondence: daniela.pietrobon@unipd.it

Department of Biomedical Sciences, University of Padua, Padua, Italy recurrent glutammatergic transmission as the basis for vulnerability to CSD ignition in FHM.

Published: 28 September 2015

doi:10.1186/1129-2377-16-S1-A20

Cite this article as: Pietrobon: Cortical spreading depression and familial hemiplegic migraine 2015. The Journal of Headache and Pain 201516 (Suppl 1):A20.
Submit your manuscript to a SpringerOpen ${ }^{\circ}$ journal and benefit from:

- Convenient online submission

- Rigorous peer review

- Immediate publication on acceptance

- Open access: articles freely available online

- High visibility within the field

- Retaining the copyright to your article
SpringerOpen ${ }^{\circ}$

(c) 2015 Pietrobon This is an Open Access article distributed under the terms of the Creative Commons Attribution License (http:// creativecommons.org/licenses/by/4.0), which permits unrestricted use, distribution, and reproduction in any medium, provided the original work is properly cited. The Creative Commons Public Domain Dedication waiver (http://creativecommons.org/publicdomain/ zero/1.0/) applies to the data made available in this article, unless otherwise stated. 